\title{
ДРЕВНЕРУССКИЕ МУЖСКИЕ ОТАПЕЛЛЯТИВНЫЕ АНТРОПОНИМЫ, ОБРАЗОВАННЫЕ ПУТЕМ ПАРАДИГМАТИЧЕСКОЙ ДЕРИВАЦИИ
}

\section{OLD RUSSIAN MALE APPELLATIVE ANTHROPONYMS THAT WERE DERIVED PARADIGMATICALLY}

\author{
БОЖЕНА ХРЫНКЕВИЧ-АДАМСКИХ
}

\begin{abstract}
Paradigmatic derivation is also referred to as conversion, zero derivation or zero affixation. It is a linguistic process that changes the paradigmatic features of an already existing word without using any affixes, which in some cases involves assigning that word to a new word class (a part of speech). This process concerns appellative lexis and proper names. The article is devoted to analyzing Old Russian male appellative anthroponyms that were formed in this way.
\end{abstract}

Bożena Hrynkiewicz-Adamskich, Uniwersytet im. Adama Mickiewicza w Poznaniu, Poznań - Polska.

Проблематику парадигматического словообразования древнерусских отапеллятивных антропонимов нельзя признать научно разработанной. Нами предпринимается попытка представить исторический лексический материал, отобранный из письменных памятников XVXVII вв. ${ }^{1}$, иллюстрирующий механизм возникновения и функционирования личных собственных наименований данного типа.

Собственные имена в основных своих закономерностях подчиняются закономерностям языка в целом. Способ словообразования, являющийся объектом исследования в настоящей статье, охватывает как ономастическую, так и нарицательную лексику. В связи с этим анализ проприальных парадигматических дериватов может дополнить знания об именном парадигматическом словообразовании как таковом. Стоит

\footnotetext{
${ }^{1}$ Источником антропонимического материала послужили: Акты социильно-экономической истории Севера России кониа XV-XVI века. Акты Соловеикого монастыря 1479-1571 г2., сост. И.3. Либерзон, Ленинград 1988; ее же, Акты соииально-экономическои истории Севера России конца XV-XVI Века. Акты Соловецкого монастыря 1572 1584 г2., Ленинград 1990; Таможенные книги Московского государства XVII века. Северный речной путь: Устюг Великий, Сольвычегодск, Тотьма, сост. А.И. Яковлев, т. І-ІІІ, Москва-Ленинград 1950-1951.
} 
однако подчеркнуть, что некоторые отношения, обнаруживаемые в апеллятивном материале, в ономастическом пространстве языка реализуются нестандартно. Согласно В.А. Никонову2, имена собственные образуют в языке „особую подсистему, в которой и общеязыковые законы преломляются специфически, и возникают свои закономерности, которых нет в языке вне ее" ${ }^{\prime \prime}$. С грамматической точки зрения отличительной чертой собственных имен, в том числе антропонимов, является то, что они, как правило, представляют собой имена существительные (или субстантивированные сочетания слов), не изменяемые по числам, нередко оформленные однотипными словообразующими и формообразующими средствами ${ }^{4}$. Названные свойства определяют некоторую специфику парадигматического словообразования древнерусских антропонимов.

Как известно, модели славянских личных собственных имен сложились в праславянскую эпоху, а затем были унаследованы древнерусским языком. С момента крещения Руси (988 г.) начался многовековой процесс, с одной стороны, борьбы с языческим мировоззрением и постепенного утверждения христианства, с другой - оттеснения традиционных имен на второй план и распространения имен христианских. Тем не менее факты употребления отапеллятивных антропонимов в качестве неофициальных, внутрисемейных имен отмечаются в древнерусских письменных памятниках вплоть до XVII столетия. Мирские имена засвидетельствованы также в основах прозвищных отчеств 5 , впоследствии превратившихся в прозвищные фамилии.

Древнерусские антропонимы создавались на базе нарицательных слов. Процесс онимизации заключался в том, что исходный апеллятив, первоначально задающий неопределенное множество схожих объектов и называющий целый их класс, сужал сферу применения и номинации до единичного референта. В связи с тем что традиционные антропонимы образовывались от нарицательных слов и словосочетаний, их число могло быть практически неограниченным. Анализ исторического

2 В.А. Н и к о н о в, Имя и общество, Москва 1974, с. 6.

3 О своеобразии и системности отношений в отдельных разрядах ономастической лексики см. С. Р о с п о н д, Перспективы развития славянской ономастики, „Вопросы языкознания" 1962, № 4, с. 9-19. В последние годы вышли в свет многочисленные разработки по „ономастической грамматике”, учитывающие специфику закономерностей, обнаруживаемых в группе собственных имен, в том числе: Н.В. П о д о л ь с к а я, Проблемы ономастического словообразования (К постановке вопроса), „Вопросы языкознания” 1990, № 3, с. 40-53.

4 В.Д. Б о н д а л е т о в, Русская ономастика, Москва 1983, с. 34-35.

5 Большинство анализируемых нами в настоящей статье форм реконструировано по патронимам. 
антропонимического материала показывает, что в качестве мотивирующих слов засвидетельствованы самые разнообразные апеллятивы древнерусского языка. По мнению Е. Куриловича6, каждому семантическому классу, для которого нарицательное имя существительное оказывается в отношении доминирования, присуща способность создать дейктический подкласс, охватывающий собственные имена существительные (наименования). В свою очередь, Я. Кухарж 7 подчеркивает, что лишь существительным свойственна абсолютная номинативная значимость, и поэтому они могут транспонировать содержание слов остальных номинативных частей речи (прилагательных, глаголов, наречий). В отношении возможности онимизации различных конструкций и даже предложений упомянутый исследователь отмечает, что условием приобретения ими номинативной функции является способность извлечься из синтаксических отношений предложения. Согласно Я. Кухаржу8, в рамках категории слова такой способностью обладает лишь существительное в именительном падеже, не обремененное дополнительной синтаксической нагрузкой. Иными словами, для того чтобы „стать именем собственным”, необходимо „превратиться в существительное”. Все несуществительные при переходе в класс онимов подвергаются субстантивации, что выражается в их словообразовании, словоизменении и функционировании в предложении ${ }^{9}$.

Соотносящееся с апеллятивом данного языка имя собственное может возникнуть в результате прямого переноса имени нарицательного в разряд онимов. В таком случае имя собственное формально полностью совпадает с мотивирующим его апеллятивом. В лингвистической литературе употребляются разные термины для обозначения такого способа образования собственных имен, а именно: „семантическая деривация", „метафорический/ метонимический переход”, „онимизация апеллятива"10. Среди отапеллятивных имен собственных имеются также единицы, образованные морфемным способом. Его разновидностью является парадигматическое словопроизводство. Термин „парадигматическая деривация" используется в настоящее время исследова-

${ }^{6} \mathrm{~J} . \mathrm{K}$ u r y $\nmid$ o w i c z, The linguistic status of proper nouns (names), "Onomastica” 1980, nr XXV, c. 9.

7 Я. К у х а р ж, К общей характеристике номинации, „Travaux linguistique de Prague, III: Études structurales dédiées au VIe Congrès des slavistes", Prague 1968, c. 121-123.

8 Там же, с. 125.

9 Теория и методика ономастических исследований, отв. ред. А.П. Непокупный, Москва 1986, с. 38-39.

10 А.В. С у п е р а н с к а я, Структура имени собственного (фонология и морфология), Москва 1969, с. 92-93; А. C i e śl i k o w a, Staropolskie odapelatywne nazwy osobowe. Proces onimizacji, Wrocław-Warszawa-Kraków 1990, c. 200-212. 
телями наравне с термином „конверсия” 11, „нулевая аффиксация” 12, „флективная деривация"13. Как было уже сказано, вопросы парадигматического словообразования славянских личных собственных имен еще не получили достаточного освещения ${ }^{14}$. Имеющиеся научные разработки посвящены в основном анализу нарицательных слов, образованных данным способом ${ }^{15}$.

Теорию конверсии на материале нарицательной лексики английского языка разработал А.И. Смирницкий. По его определению16, „конверсия есть такой вид словопроизводства, при котором словообразовательным средством выступает т о л ь к о парадигма слова". Изменение флективных аффиксов сопровождается изменением синтаксических свойств. По справедливому замечанию Б. Докулиля 17 , понятие конверсии в славянских языках представляется более широким, чем в системе английского языка. Так, для английской конверсии характерно то, что с ней неразрывно связано изменение категории части речи, напр.: kiss 'целовать' $\rightarrow$ kiss 'поцелуй'. В свою очередь, в славянских языках - благодаря их парадигматическому разнообразию - возможна и внутрикатегориальная конверсия, т. е. конверсия в рамках одной части речи, напр., кум $\rightarrow$ кума, супруг $\rightarrow$ супруга, физика $\rightarrow$ физик. Таким образом, конверсия в славянских языках заключается в создании нового слова на базе ранее существовавшего слова без изменения

${ }^{11}$ M. D o k u 1 i l, Teoria derywacji, Wrocław-Warszawa-Kraków-Gdańsk 1979; Ю.С. М а с л о в, Морфологическая конверсия в славянских языках, [в:] Сравнительно-типологическе исследования славянских языков и литератур (к IX Международному съезду славистов). Сборник статей, Ленинград 1983, с. 6-24.

12 В.В. Л о п а т и н, Нулевая аффриксаиия в системе русского словообразования, „Вопросы языкознания" 1966, № 1, с. 57-62; Е.А. 3 е м с к а я, Современный русский язык. Словообразование, Москва 1973, с. 175-176.

13 P. S m o c z y ń s k i, O derywacji fleksyjnej w stowiańskiej onomastyce. Zarys problematyki, [в:] I Międzynarodowa Slawistyczna Konferencja Onomastyczna w Krakowie w dniach 22-24 października 1959 roku: księga referatów, red. W. Taszycki, Wrocław 1961, c. 147-160; П.Н. С т р е л к о в, Флективное словообразование коррелятивных существительных женского рода $b$ современном русском языке, „Ученые записки Горьковского педагогического института" 1967, вып. 68, с. 145-162; Cz. K o s y l, Z historii użycia terminu „derywacja" w lingwistyce, [в:] Pojęcie derywacji w lingwistyce, red. J. Bartmiński, Lublin 1981, c. $13-29$.

14 Исключение здесь составляет монография по древнепольским антропонимам, возникшим путем парадигматической деривации: А. C i e śl i k o w a, Derywacja paradygmatyczna w staropolskiej antroponimii, Kraków 1991.

${ }^{15} \mathrm{~K}$. W a s z a k o w a, Stowotwórstwo wspótczesnego języka polskiego. Rzeczowniki z formantami paradygmatycznymi, Warszawa 1993; Э. С е к е ж и ц к и, Парадигматические существительные в русском и польском языке, Szczесіп 1996.

16 А.И. С м и р н и ц к и й, Лексикология английского языка, Москва 1956, с. 71.

17 M. D o k u l i l, указ. соч., с. 90. 
основы и без использования каких-либо словообразовательных аффиксов, т. е. исключительно путем его перевода в другую парадигму (изменения флективной характеристики). Образованное в результате конверсии слово приобретает формы словоизменения той части языка, к которой оно примыкает.

Что касается древнерусских парадигматических антропонимов и мотивирующих их нарицательных слов, обнаруживаются следующие соотносительные пары: 1 . существительное (антропоним) $\leftarrow$ существительное (апеллятив), а также 2. существительное (антропоним) $\leftarrow$ глагол (апеллятив), 3. существительное (антропоним) $\leftarrow$ прилагательное (апеллятив). В связи с этим презентация лексического материала проводится нами с учетом деления на внутри- и межкатегориальные дериваты.

ВНУТРИКАТЕГОРИАЛЬНЫЕ ПАРАДИГМАТИЧЕСКИЕ ДЕРИВАТЫ (образованные в рамках одной части речи, т. е. имени существительного)

\section{1. Антропонимы, образованные путем парадигматической деривации от имен существительных}

\section{1. -а : -Ø (нариц.)}

Бобра* : бобр 'животное Castor fiber; шкурка, мех бобра' (СлРЯ I 253), диал. 'название человека за черный цвет волос', яросл. (СРНГ ІІІ 38). (K III: ...у Зотия Ипполитова Бобриных 1678. Ср. А 600: Василью Боброву, дат. п. 1576, Бобр Никитин сын 1578, сп. XVII в.)

Зимака* : зимак 'восходы озимой ржи', урал.; 'животное, родившееся зимой', урал.; 'поросенок, родившийся зимой', перм. (СРНГ ХІ 272).

(K III: Мелентей Терентьев Зимакин 1679)

Мурога* : мурог 'луговая местность, покрытая сочной травой' (СлРЯ IX 310); диал. 'густая трава, обычно на деревенской улице', брян.; 'мелкая низкая трава', тобол.; 'растение Polygonum aviculare L., спорыш или горец птичий', брян. (СРНГ XVIII 358).

(K III: Никифора Дмитриева Мурогина, род. п. 1680)

Облада : облад, диал. 'порядок, лад' (СРНГ XXII 81). Ср. облаживать, обладить ' у(из, на)ладить, о(по)править, изготовить, отделав совсем, кругом' (Д II 592), диал. 'приводить в хорошее состояние; поправлять, починять', петерб., новг., пск., смол.; 'украшивать, отделывать', свердл. (СРНГ ХХІІ 81).

(K I: Афонасей Облада 1636)

Олуха* : олух 'глупый человек, дурак, болван' (СлРЯ ХІІ 361, Д II 672, СРНГ XXIII 192).

(K I: Ондрей Олухин 1636) 
Очка* / Ачка* : очко 'дыра, лазок, маленькое отверстие, проемец, просвет'; 'леток в улье'; 'петля веревочная, нитяная'; 'глазок, пупок, почка (у растений)' (Д II 664); диал. 'глаз', дон., арх.; 'петля на конце чалки-веревки для привязывания судна к берегу', волж. (СРНГ XXV 70).

(K I: ...у Аникея Ачкина 1633, Внифантей Очкин 1635)

Поздыша* : поздым 'поздний, осенний цыпленок' (Д ІІІ 231); диал. 'детеныш или птенец, родившийся после обычного срока', перм., свердл., арх.; 'последний ребенок, поздний ребенок', челяб., южн.-сиб., амур.; 'о человеке маленького роста', южн.-сиб.; 'растение, посаженное, выросшее или созревшее поздно', перм., иркут. (СРНГ XXVIII 330).

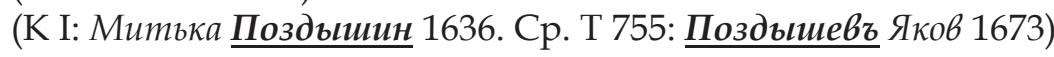

$$
\text { 1.2. - } \text { : - -а (нариц.) }
$$

Басан* : басана, диал. 'щеголь, франт', сев.-вост. (СРНГ II 128, Д I 52). (К III: Василей АфонасьеҺ Басанов 1679)

Вахнь-* (м) : Вахня, диал. 'рыба Gadus aeglefinus, семейства тресковых; пикша', камч. (Д I 168, Ф I 280). Нельзя, однако, исключить, что данная форма представляет собой дериват со сложным суффиксом -хно, образованный от сокращенной основы одного из христианских имен, начинающихся на Ва-, напр.: Василий, Валерий и т. п., или же от сокращенной основы имени Иван с дополнительным усечением начального гласного. Возможен также парадигматический дериват от диал. Вахонистый 'ретивый, бодрый, резвый' (СРНГ IV 75).

(К III: Данило Васильев Вахневых 1680 / Данило Васильев Вахнев 1680)

Вислень* (м) : висленя (ж) 'баловень, лентяй; неработающий член семьи', волог. (СРНГ IV 296).

(А 579: Брага Висленев 1575; Т 142: Вислень 1392; В 68: Висленевы XVI-XVII в.)

Гундор* : гундора, диал. 'болтун, говорун'; 'толстый, неуклюжий, тяжелый на подъем человек', новг., моск. (Д I 408, СРНГ VII 232). См. также диал. гундорить 'говорить, болтать, беседовать, гуторить', твер. (Д, там же).

(А 206: ...съ Яковом з Гундором 1555, сп. XVI в.; К I: ...на Луке Гундорове 1634, Русин Гундоров 1634)

Дудор* : дудора, диал. 'хлам, шарабара, дрянные пожитки', твер., перм.; 'дурак, дура', пенз., новг. (Д I 500, СРНГ VIII 250); 'хлам, сорняк', вят. (Ф I 550). Ср. дудор 'что-либо непригодное, плохое; хлам, мусор, дрянь, рухлядь', вят., перм.; 'дым, чад' (СРНГ VIII 250). (А 19: Роман Иванов сын Игумнова Дудорова 1509, сп. XVI в.) 
Жегуль* (м) : жегуля (ж) 'запальник к огнестрельному оружию' (СлРЯ V 79). Ср. также диал. жегулиться 'зябнуть', олон., арх. (СРНГ IX 99). (К I: Афонасья Жегулева, род. п. 1636)

Завьял : завьяла (ж), диал. 'метель, вьюга', онеж., калуж.; завьяла (м и ж) 'вялый, медлительный человек', влад., нижегор. (Д I 564, СРНГ IX 348). Ср. также завъяиичный 'занесенный чем-либо (снегом, песком)' (СлРЯ V 161).

(K I: Завья Алексеев 1633, Завья Якимов 1633, Завьял Наумов 1633, Завьял Михайлов 1635, Завья Фалелеев 1636, Рычко Завьялов 1634, Ооронасей Завьялов 1636, Иван завьялов 1636)

Колег* : ко́лега, диал. 'брюква', перм.; колега́ 'слякоть, мокрый снег, непогода', волог. (СРНГ XIV 122).

(К III: Илья Никитин Колегов 1679)

(Кочур) Кочюр* : кочура, диал. 'хилый человек', череп. (Г 51). Ср.: качюриться, кочюритвся, окачуриться 'находиться при смерти; умирать', олон.; 'корчиться', костром.; 'гримасничать', пск., твер. (СРНГ XV 136); 'напиться до беспамятства'; 'угореть', кашинск. (Ф II 214). Ср. также диал. кочура 'укладка сжатого хлеба из 10 или 14-20 снопов', волог., арх.; качур-дедко 'прадед', олон. (СРНГ XV 135). Однако не исключена и связь с диал. качуръ 'селезень', новорос. (Д II 100).

(А 240: Василей Григорьев сын Кочюрова, Киприан Григорьев сын

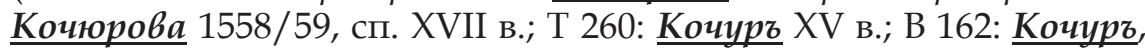
конец XV в.)

Мотох : мотоха, диал. 'напрасная трата времени', перм. (СРНГ XVIII 303). (K I: Ивану Никитину сыну Мотохову, дат. п. 1633)

Незговор : несговора (м и ж), диал. 'о несговорчивом человеке', влад. (СРНГ XXI 149). Ср. диал. несговорный 'несговорчивый', твер., пск., арх., костром., вдад., тул., калуж., тобол., енис.; 'неприличный, бранный', сев. (СРНГ, там же).

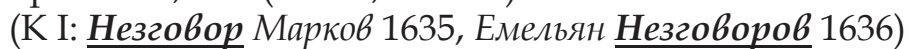

Чупр* : чупра, диал. 'замарашка', вят. (Д IV 615).

(K I: Иван Петров сын Чупров 1636 / Иван Петров сын Чудровых 1636)

Шевырь : шевыря 'человек, который ворошится' (Д IV 626).

(А 522: Григорей Ортемъев сын Шевыръ 1574)

Шмар* : шмара 'цвиль, тина на воде, ряска, цвет воды, растение Lemna L.' (Д IV 640).

(К III: ...у Григорья Васильева Шмаровых 1678)

Шуст* : шуста, диал. 'шуба' (?), кал.; 'мох, которым обрастают пни деревьев', сиб. (Д IV 649). См. также диал. шустать 'шастать, оталкивать (овес, ячмень)', тамб.; 'есть, жрать, уплетать, охлестывать, уписывать', арх.; 'чистить и гладить внутри (ствол, ружье)' (Д, там же). (K III: Семен Лаврентьев Шустов 1679 / Семен Лаврентьев Шусто$\underline{b u x}$ 1680) 


\section{3. -о : -а (нариц.)}

Заико* : заика 'тот, кто заикается, говорит заикаясь' (Д I 580), диал. 'об изморози, инее в избе', пинеж., арх.; 'хороводная игра', арх., КАССР (СРНГ X 106). Ср. заикаться 'говорить с затруднением, запинаясь' (СлРЯ V 201). Возможно, однако, что изучаемый антропоним мотивирован диал. зайко 'заяц', олон., арх., КАССР, Волго-Камье, вят., перм.; 'об огне (в разговоре с детьми)', волог., твер. (СРНГ, там же).

(K III: Григорей Михайлов Зaиков 1678)

(Мальго) Малго* : мальга 'кроха, крошка, малешь, мелочь' (Д II 294); диал. 'младший сын; младший в роде', твер.; 'младшая из сестер с одинаковыми именами', новг.; 'деревянное топорище', арх. (СРНГ XVII, 342-343).

(А 213: Иванку Малгову, дат. п. 1556, сп. XVII в. Ср. А 235: Малга Федоров сын Ушакова 1558, сп. XVII в.)

Подшивало* : подщивала 'кто подшивает что-либо'; 'остряк, кто любит и умеет трунить, остро насмехаться' (Д ІІІ 217).

(К III: Семен Дмитриев Поошивалов 1679, Яков Дмитриев Подииваловых 1679)

Трухо : труха 'измельчившееся сено, солома' (Д IV 438, Ф IV 111), диал. 'о трусливом человеке', Забайкалье (CPHГ XLV 173), или диал. трух 'гниющие листья, трава, деревья', свердл. (СРНГ, там же). Ср. еще диал. трухавый старик 'хилый, дряхлый' (Д, там же). Однако не исключено, что анализируемый антропоним является дериватом от христианского имени Трифон (> Труфан > Трухо). (A 731: Tpyxo Mamoeeb сын 1580; Т 459: pyxa 1557; В 323: $\underline{\text { Tpyxa }}$ 1540)

\section{4. -а : -ей (нариц.)}

(десуффиксация и прибавление форманта - $а$ в процессе онимизации)

Опухта* : опухтей, диал. 'человек с опухшим лицом', олон. (СРНГ XXIII 317). Ср. также опухтаться 'то же, что опухаться', дон. (СРНГ, там же).

(А 759: Иван Васильев сын Опухтина 1581)

$$
\text { 1.5. -ей : -а (нариц.) }
$$

(устранение форманта - $a$ и суффиксация в процессе онимизации)

Пукшей* : пукща, диал. 'лесная птица - соя' (?), арх. (Д ІІІ 537, Ф ІІІ 404). (А 97: Кондратей Иванов сын Пукшеева 1543, сп. XVII в.)

Юкшей* : юкща, диал. 'лыжный ремень, стремлянка в лыжах', колым., камч. (Д IV 667, Ф IV 529).

(А 588: Кузма Иванов сын Юкшеева 1575) 
1.6. Мягкий подтип мужского склонения : женское склонение на мягкий согласный (нариц.)

Проесть* (м) : проесть (ж) 'рана, язва'; 'расходы на еду, жизнь; пропитание' (СлРЯ XX 127-128, Д III 528). См. также глагол прољсти 'прогрызть, продырявить насквозь'; 'израсходовать, потратить на еду, на жизнь' (СлРЯ, там же; Д, там же).

(K I: Стефана Ивановича Проестева, род. п. 1636)

1.7. Мягкий подтип мужского склонения : твердый подтип мужского склонения (нариц.)

Кокурь* (м) : кокур (м), диал. 'корзинка для ягод', сиб.; 'пшеничный хлебец', костром. (СРНГ XIV 104).

(K III: Борис Гаврилов Кокуревых 1680)

Чекаль* (м) : чекал (м), диал. 'земляной зайчик или мышь Ochotona pusilla', сиб., оренб. (Д IV 586, Ф IV 324).

(K III: ... у Федора Чекалева 1678)

Чирь* (м) : чир (м), диал. 'тонкий, чистый лед, когда вода лишь начинает мерзнуть; кора, череп, тонкий ледок по снегу', сиб.; 'крупяной, жесткий и рассыпчатый снег', арх.; 'рыба Salmo nasus, Coregonus nasus', печор. (Д, там же).

(K III: Тимофей $\underline{\text { чирев } 1679)}$

1.8. Мягкий подтип женского склонения на -a : женское склонение на мягкий согласный (нариц.)

Тюся (ж) : тюсь (ж), диал. 'крупная ячная крупа, дранка', перм.-черд. (Д IV 452).

(K III: Федор Тюся 1679)

\section{МЕЖКАТЕГОРИАЛЬНЫЕ ПАРАДИГМАТИЧЕСКИЕ ДЕРИВАТЫ (образованные в результате перехода слова из одной части речи в другую)}

\section{2. Отглагольные антропонимы}

$$
\text { 2.1. -а : (нариц.) }
$$

Боча* (ж) : бочить, бочениться, диал. 'наклоняться на бок', яросл., костром., вят.; 'важничать, приосаниваться; чваниться', яросл., вят., перм.; 'сердиться, дуться', вят.; 'упираться, не соглашаться с чем-либо', перм. (СРНГ III 140-141).

(К III: Иван Иванов Бочиных 1678) 
Оболта* : оболтать 'оговорить, оклеветать' (Д II 566); диал. обалтывать 'оклеветать, обговорить кого-либо', тобол. (СРНГ ХXI 347). См. также оболтать себе ноги 'обить, устать бегая', (Д, там же); оболтус, оболтень 'повеса, невежа, шатун, лентяй, неотесанный, грубый и глупый' (Д, там же).

(К III: Иван Тимофиев Оболтин 1680)

Обота* : оботать, диал. 'пройти (большое расстояние), отмахать; обойти (большое пространство)', оботаться 'загрязниться, запачкаться', новг., 'сойти с ума, свихнуться', олон. (СРНГ ХХІІ 184). См. также диал. обот 'наружная часть колеса в виде круга', перм. (СРНГ, там же). (K III: Сергий Оботин 1679)

Четырка* : четыркать, диал. 'ходить на четырках, на четвереньках, лазить, ползать на корачках', сиб. (Д IV 602). Ср. также четырки (мн. ч.) 'четыре ноги, лапы животных; руки и ноги человека' (Д, там же).

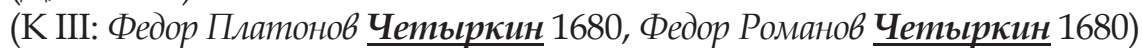

\section{2. -Ø : (нариц.)}

Клюс* (м) : клюсать, диал. 'ездить, двигаться не прямым путем, отклоняться в стороны, колесить', новг. (СРНГ ХІІІ 322). Ср. еще клюся 'лошак', 'о рабочем скоте', 'рабочая лошадь' (СлРЯ VII 182).

(K III: Тимофий Афронасьев Клюсовых 1679)

Конос* : коноситься, диал. 'сердиться', новосиб. (СРНГ ХIV 268). (K I: Ларион Коносов 1636)

Повыш* (м) : повышать, диал. 'делать или поднимать выше, возвышать несколько, немного; давать высшее место, звание, чин' (Д III 150). (K III: Богдан Повынев 1679)

Послов'-* (ж) : пословить, диал. 'потакать, поддакивать', вост., арх. (Д III 335, СРНГ XXX 179-180). См. также диал. пословный 'послушный, повинующийся, исполнительный, покорный', сев. (Д ІІІ 334); 'разговорчивый', пинеж., арх. (СРНГ, там же).

(K I: Герасима Пословина, род. п. 1635)

Тюш* (м) : тюшиться, диал. 'суетиться, хлопотать', костром. (Д IV 452, СРНГ XLVI 51); 'медленно делать что-либо, копаться', волог.; 'сердиться, дуться', олон.; тюшить 'доить корову', тул. (СРНГ, там же). Возможна также связь с диал. тюша (м и ж) 'о толстом человеке', вят.; 'курица', новг. (СРНГ XLVI 50).

(K III: Епифан Гаврилов Тюшев 1679)

Шевель* (м) : шевелить 'трогать, перебирать, двигать; ворочать, шелошить' (Д IV 626). Ср. шевелила 'ворошила, кто все хватает, роется пальцами', диал. шевелюга 'узорочье, изурочье, уродина, выродок', apx. (Д, там же).

(К I: Борис ЯковлеВ сын Шевелев 1633, Кирило Шевелев 1634) 
Шемет* (м) : шеметать, шеметиться 'заниматься бездельем, пустячками, метаться туда и сюда, суетиться попусту' (Д IV 628). Ср. еще шеметень, шеметун, шеметуха 'хлопотун, суета' (Д, там же). (K III: Лазарь Гаврилов Шеметов 1678)

2.3. Твердый подтип мужского склонения : действительное причастие прошедшего времени на - 1 (нариц.)

Поспел (м) : посnел; в основу антропонима легло девербативное образование в форме действительного причастия прошедшего времени на $-\bumpeq$ от посnевать, поспеть 'угодить впору, быть где ко сроку, не опоздать; созревать, спеть (о растениях); войти в годы (о людях); увариться, испечься, дожариться, быть готовым (о пище)' (Д III 340). Ср. поспелка 'девушка в поре' (Д, там же).

(K I: Поспел Фирсов 1633, Поспел Васильев 1634, Поспел Белкин 1635, Поспел Мириловых 1636, Поспел Поздеев 1636, Шестак Пцопелов 1633, Бажен Поспелов 1634, Яков Поспелов 1636)

\section{3. Отадъективные антропонимы}

\section{1. -Ø : (нариц.)}

(Безъим) Безим* : безъименный 'бедный' или безъимянный 'не имеющий имени' (СлРЯ I 129, Д І 80).

(K I: Бажен Осипов сын Безимов 1636)

Безнос* : безносый 'безносый' (СлРЯ I 121); ср. диал. безносик 'прозвище человека с маленьким носом', костром. (СРНГ ІІ 194).

(K III: Фаддей Михайлов Безносов 1679; Т 100: Василей Безносъ 1485, Левонтикъ Безносъ 1491. Ср. Т 100: Оска Карпов Безносой 1654)

(Бессол $\left.{ }^{*}\right)$ Безсол* : бессолыи, диал. 'несоленый, недосоленный', арх.; 'недогадливый, бестолковый, глупый', волог., арх. (СРНГ II 277). Ср. бессольный 'не содержащий в себе соли, несоленый' (Д I 74).

(К III: Василей Юрьељ Безсолов 1679)

Кос* : косой 'о людях, имеющих физический недостаток (косоглазие, хромоту и т. п.)' (СлРЯ VII 366); 'косоглазый' (Д II 174); диал. 'хромой', дон.; 'одноглазый', краснодар., ворон., курск.; 'враждебный', курск. (СРНГ ХV 64-65).

(К III: Иван Софонов Косовых 1678, Федор Елисеев Косовых 1679, Федор Семенов Косовых 1679)

Неклюд* : неклюжий 'неуклюжий, некрасивый, невзрачный' (Д II 521). (К III: Дмитрей Фалелиев Неклюдовых 1680)

Пахорук : пахорукой, пахорукий, диал. 'без одной или обеих рук; без пальцев на руках', арх., свердл., иркут.; 'с поврежденной, больной или парализованной рукой', волог., арх., мурман; 'медлительный, не- 
умелый, неловкий', волог., арх., свердл., перм.; 'рассеянный, невнимательный"', свердл., арх.; 'левша', волог., арх. (СРНГ XXV 293). Ср. также диал. пахорука, пахоруча 'человек без одной или обеих рук; без пальцев на руках', волог., свердл.; 'человек, плохо владеющий рукой (руками)', волог.; 'неловкий, неповоротливый человек', волог. (СРНГ XXV 293-294).

(К III: Сидор Яковлев Пахорук 1679, Александр Козьмин Пахорукой 1679)

Чепур : чепурной, чепорный 'мелочной, щепетливый, прихотливый до мелочей из одежды' (Д IV 582). Ср. также диал. чапуриться, чепуриться 'надыматься, важничать, чваниться; одеваться щеголевато' (Д, там же).

(K I: Иван Чепyp 1633)

\section{2. -а : (нариц.)}

Биза* / Бизь* : бизый, бизой, диал. 'близкорукий, подслеповатый', яросл., костром. (СРНГ II 290).

(K I: Илье Григорьеву сыну Бизину, дат. п. 1636)

Чега* : чеглый 'беглый, совершивший побег' (Д IV 586).

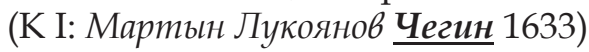

Сопоставление ономастических разработок с трудами по общему словообразованию обнаруживает существенные расхождения в трактовке проблематики парадигматического словопроизводства и применяемой в ней терминологии. Согласно А. Чесликовой ${ }^{18}$, анализируя собственные имена, нельзя упускать из виду специфику онимов, а именно своеобразные пути развития их состава, уникальные функции, выполняемые ими, и прежде всего отсутствие у онимов лексического значения. Как кажется, даже в случае личных наименований, возникших в результате прямого перехода апеллятивов в разряд собственных имен, лучше не прибегать к понятию семантического переноса, поскольку здесь происходит регулярная смена парадигм „неодушевленного" и "одушевленного” склонения (в частности это касается антропонимов, мотивированных мужскими неодушевленными существительными). В польском языке в соответствующих условиях наблюдается изменение „безлично-мужского” склонения на „лично-мужское”.

Необходимо подчеркнуть, что в настоящей статье рассматриваются в основном отапеллятивные антропонимы, не имеющие точных аналогов в нарицательной лексике. Формы такого типа в количественном смысле преобладают в изученном материале. В связи с этим встает

18 A. C i e śl i k o w a, Derywacja paradygmatyczna..., указ. соч., с. 14. 
вопрос: произошла ли в их случае парадигматическая деривация на апеллятивном уровне (апеллятив $\rightarrow$ апеллятивный парадигматический дериват $\rightarrow$ антропоним) или же на проприальном (апеллятив $\rightarrow$ [антропоним, формально полностью совпадающий с мотивирующим апеллятивом] $\rightarrow$ проприальный парадигматический дериват). Надо полагать, что в большинстве исследуемых случаев имеем дело с имятворчеством второго типа, с возможным пропуском промежуточной стадии процесса онимизации.

Немногочисленны примеры наименований, представленных в источниках двумя параллельными формами, - антропонимом, возникшим в результате прямого переноса имени нарицательного в разряд имен собственных, и парадигматическим дериватом с той же основой, напр.: Бобра* : Бобр $(\leftarrow$ бобр), Мальго* : Мальга $(\leftarrow$ мальга), Поздыша* : Поздыш* (ヶnоздым).

В анализируемом антропонимическом материале засвидетельствована форма Дудор*, в отношении которой возникает трудность установления направления мотивации, так как в диалектах подтверждено сосуществование соотносящихся по конверсии существительных дудора и дудор со значением 'хлам, сорняк, мусор' (см. выше).

Задумываясь о причинах возникновения парадигматических образований в древнерусской антропонимии, целесообразно вспомнить о переиначивании как об особом словообразовательном способе ${ }^{19}$. Нестандартная структура свойственна, например, многим словам, относящимся к обсценной лексике. Кроме того, известны запреты на произнесение имени Бога, а также настоящих названий некоторых животных, например медведя. В прошлом перемена личных имен практиковалась у многих народов, в том числе у славян ${ }^{20}$. В названных случаях переиначивание обуславливалось табуистическими факторами.

Как кажется, формальное отличие парадигматических имен собственных от легших в их основу немаркированных нарицательных слов, соотносящихся с ними по конверсии, могло также служить различительным признаком.

Не исключено, конечно, и то, что некоторые наименования рассматриваемого типа могли появиться вследствие ошибки или застывания и последующего закрепления в языке форм косвенных падежей исходных антропонимов, в основном родительного (напр.: мурог $\rightarrow$ Мурог $\rightarrow$ [кого? чей?] Мурога $\rightarrow$ Мурогин). По всей вероятности, в данном случае изменялось восприятие конечного звука, который

${ }^{19}$ M. D o k u 1 i l, указ. соч., с. 37.

20 Д.К. 3 е л е н и н, Табу слов у народов восточной ЕВропы и северной Азии, II. Запреты В домашней жизни, [в:] Сборник Музея археологии и этнографии, т. IX, Ленинград 1929, с. 160-165. 
трактовался теперь уже не как флективное окончание, но как формоизменительный аффикс.

Отметим также возможность вполне естественной с логической точки зрения маскулинизации в случае наименований мужчин, мотивированных апеллятивами женского рода. Правдоподобным представляется, например, следующий механизм возниковения отмеченного в исследованных нами источниках прозвищного отчества Басанов: басана $\rightarrow$ Басана $\rightarrow$ Басан $\rightarrow$ Басанов. К сожалению, скудость имеющегося в нашем распоряжении антропонимического материала не позволяет проследить ни момент появления, ни пути развития подобных форм.

Подытоживая вышесказанное, следует упомянуть, что парадигматические дериваты получили довольно ограниченное распространение в исследуемом антропонимическом материале ${ }^{21}$. Среди них в количественном смысле преобладают внутрикатегориальные образования, т. е. антропонимы, созданные на базе имен существительных. В анализируемых источниках засвидетельствованы также отапеллятивные наименования, образованные от основ глаголов и имен прилагательных. Отапеллятивные антропонимы, возникшие путем парадигматической деривации, реконструированы нами по патронимическим формам. Многие из патронимических образований, имеющие основой проприальные парадигматические дериваты, превратились со временем в патронимические фамилии. Они пополняют состав фамилий, бытующих в России, и сказываются на его разнообразии.

\section{Список используемых сокращений}

\section{1. Источники}

А - Акты социально-экономической истории Севера России конца XV-XVI века. Акты Соловецккого монастыря 1479-1571 г2., сост. И.3. Либерзон, Ленинград 1988; ее же, Акты социально-экономической истории Севера России кониа XV-XVI века. Акты Соловецкого монастыря 1572-1584 г2., Ленинград 1990.

K - Таможенные книги Московского государства XVII века. Северный речной путь: Устюг Великий, Сольвычегодск, Тотьма, сост. А.И. Яковлев, т. I-III, Москва-Ленинград 1950-1951.

\section{2. Словари}

В - С.Б. В е с е л о в с к и й, Ономастикон. Древнерусские имена, прозвища и фрамилии, Москва 1974.

${ }^{21}$ Cр. P. S m о с z у ń s k i, указ. соч., с. 159. 


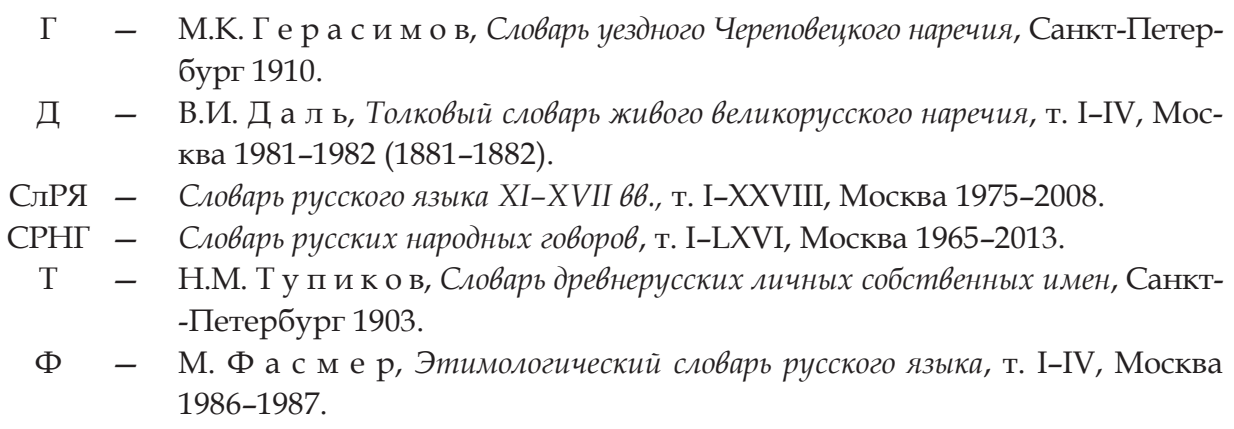

\section{3. Языки, диалекты и территории}

\begin{tabular}{|c|c|c|c|c|c|}
\hline амур. & - & амурский & новорос. & - & новороссийский \\
\hline apx. & - & архангельский & новосиб. & - & новосибирский \\
\hline брян. & - & брянский & олон. & - & олонецкий \\
\hline вдад. & - & владимирский & оренб. & - & оренбургский \\
\hline волж. & - & волжский & перм. & - & пермский \\
\hline волог. & - & вологодский & петерб. & - & петербургский \\
\hline ворон. & - & воронежский & печор. & - & печорский \\
\hline вост. & - & восточный & пинеж. & - & пинежский \\
\hline вят. & - & вятский & пск. & - & псковский \\
\hline дон. & - & дОНской & свердл. & - & свердловский \\
\hline енис. & - & енисейский & сев. & - & северный \\
\hline иркут. & - & иркутский & сев.-вост. & - & северо-восточный \\
\hline калуж. & - & калужский & сиб. & - & сибирский \\
\hline камч. & - & камчатский & смол. & - & смоленский \\
\hline КАССР & - & Карельская АССР & тамб. & - & тамбовский \\
\hline кашинск. & - & кашинский & твер. & - & тверской \\
\hline колым. & - & колымский & тобол. & - & тобольский \\
\hline костром. & - & костромской & тул. & - & тульский \\
\hline краснодар. & - & краснодарский & урал. & - & уральский \\
\hline курск. & - & курский & челяб. & - & челябинский \\
\hline MOCK. & - & московскИй & черд. & - & чердынский \\
\hline мурман. & - & мурманский & череп. & - & череповецкий \\
\hline нижегор. & - & нижегордский & южн.-сиб. & - & южно-сибирский \\
\hline НОВг. & - & новгородский & яросл. & - & ярославский \\
\hline
\end{tabular}

\section{4. Прочие сокращения}

\begin{tabular}{|c|c|c|c|c|c|}
\hline дат. п. & - & дательный падеж & нариц. & - & имя нарицательное \\
\hline диал. & - & диалектное & род. п. & - & родительный падеж \\
\hline Ж & - & женский род & сп. & - & спИСОК \\
\hline M & - & мужской род & * & - & реконструировано \\
\hline ч. & - & множественное число & & & по патрониму \\
\hline
\end{tabular}


